\title{
Pintura y fotografía en el alba de sus vanguardias: Sumisiones, fusiones y revoluciones
}

\author{
JuAn PANDo DEspierto
}

ARTE E HISTORIA: NUEVAS TÉCNICAS, GUERRAS Y CAUDILLOS

En el comienzo del siglo $x x$ el arte, templo donde se guardaban celosamente los más severos signos conductuales de regímenes, sociedades y políticas, había literalmente estallado, como el viejo Partenón, convertido en polvorín griego y volado por una granada veneciana en 1691 durante el asedio de Atenas. Curiosamente, apenas se produjo ese gran silencio que sucede a toda declaración cataclísmica.

El conflicto se trasladaría a otras dimensiones: los choques acaecidos entre dinastías, ideologías y nacionalismos. Pueblos y sistemas, artistas y marchantes, propietarios y esclavos, reyes y pretendientes, generales y guerrilleros, voluntarios y prófugos, genios y falsificadores, todos estos combatientes de las diversas circunstancias formaban parte de una misma pugna colosal entre intereses y utopías. El público mundial asistía estupefacto a estas manifestaciones de la vanidad o la inocencia, del valor o la cobardía, que hacían ver la magnitud del combate planetario, desde los Salones de las Artes a los Consejos de Ministros, y desde los Estados Mayores a los Museos Nacionales.

De toda aquella titánica batalla habida entre academicismos y herejías, de luchas enconadas entre pontífices de la norma y amotinados de la regla, se derivó una impresionante sensación de libertad, que era, asimismo, recuperación positiva de las autonomías pensantes del hombre.

Tanta revolucionaria importancia había tenido la incursión, en la avenida de las confianzas europeas, del exquisito coraje manetiano con su obra $L e$ balcon, de 1869, como la aparición de los rifles Winchester en la guerra de Secesión norteamericana cuatro años antes. Turner, Pisarro, Millet o Zubiaurre, son caudillos de similar trascendencia reformadora a los Schlieffen, Fischer, Brussilov o Lettow von Vorbeck. Los feroces encuentros 
entre ilegitimidad y derecho, entre manumisión y esclavitud, se sucederían: desde la presentación picassiana de su bélico lienzo Les demoiselles d'Avignon, en 1907, a los ataques con gas mostaza en el frente francobelga en 1917. En esencia, se trataba de una misma guerra. En ambos casos, las violencias para la sociedad, para usanzas y culturas, eran inauditas, inesperadas, incomprensibles.

\section{DIRECCIONES E INDUCCIONES EN LAS PRIMERAS MUTACIONES}

Hacia 1865, el carácter de utilitarismo del hecho fotográfico prosigue, mientras comienza a ser sutilmente reemplazado por una insólita facultad de autoexplicación del fenómeno en si, ante las artes y la historia.

En ese paréntesis, coincidente con las magníficas series de retratos realizados por Julia Margaret Cameron en la isla de Wright (1864-1867), y

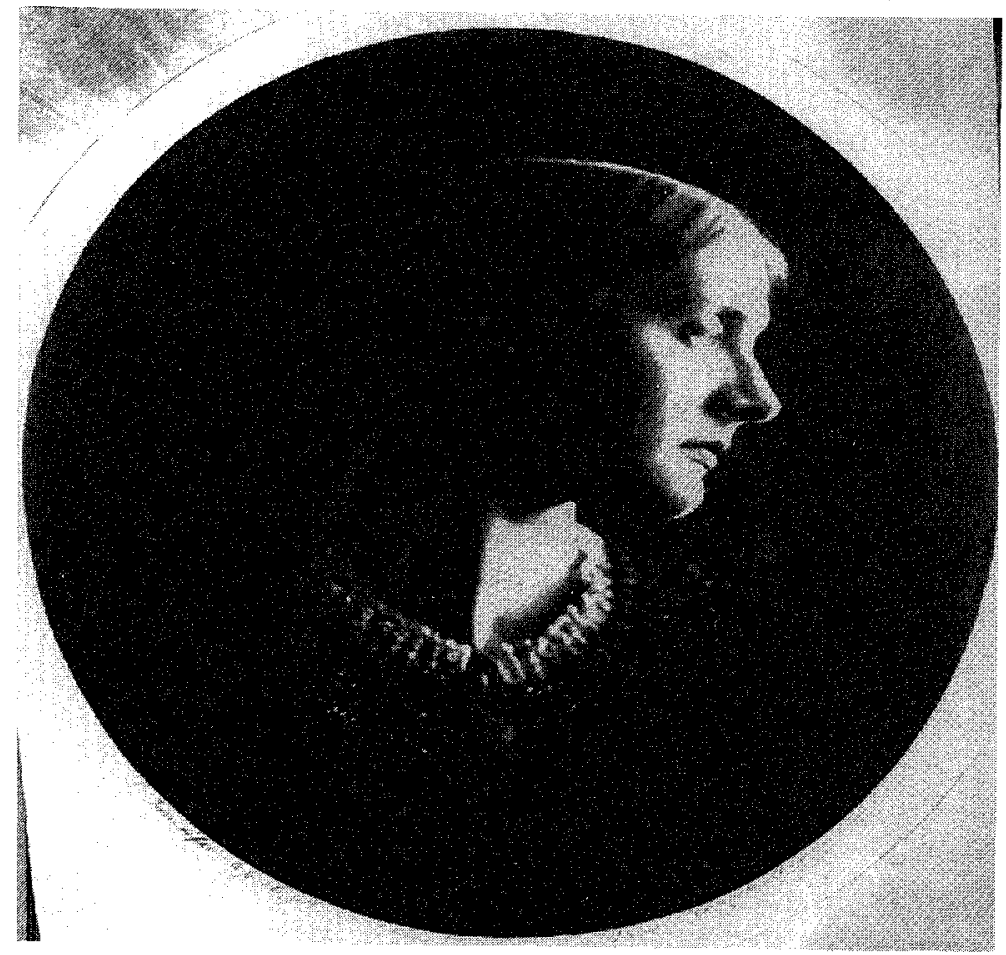

Fig. 1. Mistress Herbert Duckworth (luego señora Leslie Stephen, madre de Virginia Wolf). Original de JuLIA MaRgaret CAMERON. Copia a la albúmina, 1867. Colección Beaumont Newhall. 
los estremecedores reportajes sobre la desnudez bélica, obtenidos por Alexander Gardner y Timothy O'Sullivan en los campos de batalla de Antietam y Gettysburg (1862 y 1863), la adolescencia del nuevo método concluyó abruptamente, abriéndose enérgicamente hacia la madurez (figs. 1 y 2).

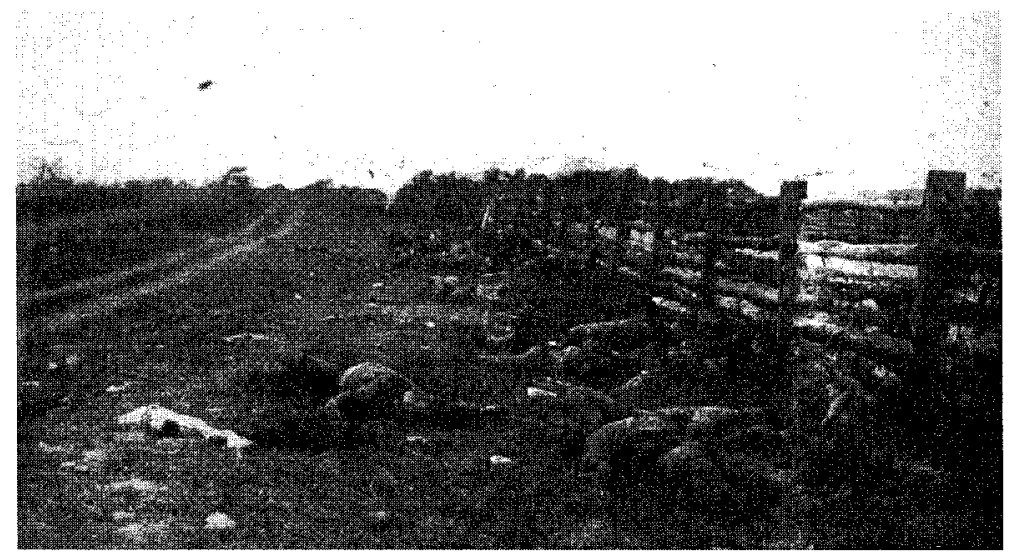

Fig. 2. Deadt at Antietam (Muertos en Antietam). Original de ALEXANDER GARDNER, realizado el 19 de septiembre de 1862 (dos días después de la acción). Library of Congress.

Inmediatamente, la fotografía dejó de ser algo aimable o convenable para el Estado o la política de las artes, convirtiéndose en un testigo incómodo de gélida y odiosa actitud, por cuanto a su crudeza exhibidora de los hechos unía una indiferencia cruel ante la emoción ajena.

Las interinidades en el retrato humano y la brutal estabilidad de la humanidad violada por si misma, sendas manifestaciones del intimismo y la inconsciencia, confundieron hondamente a críticos y practicantes del género. Las ortodoxias estéticas que hasta entonces se afanaban en explicar pacientemente la pasión de los hombres o la cólera de los sistemas, quedaron enmudecidas.

Parecía imposible que un procedimiento que, en su origen, era sólo un factor de reproducción pudiese albergar en su marco divulgativo toda la ternura y fantasía cameronianas y, al mismo tiempo, contener, en un giro despiadado, la estupidez bestial de las estrategias e ideologías homicidas entre sí que denunciaban los originales sullivianos.

Esa extraña ductilidad, en la que la certeza, la abstracción y el sentimiento cohabitaban sin pudor alguno, irritó y confundió a la ética victoriana, cuya inexpresividad e insinceridad reformista iban de consuno con su incapacidad para soportar tal diversidad de pensamientos y actividades. 
La fotografía se había atrevido a pensar, a imaginar, a interpretar la realidad vivida o el subconsciente. Algo en verdad inimaginable para un proceso considerado un mero sincronismo técnico y químico, una fuerza simulada, una acción sin espíritu (recordemos la famosa diatriba baudeleriana).

Ese primer acto revolucionario - los fotógrafos, simples mecániciens, convertidos de repente en autores creativos de la conciencia y en documentalistas perspicaces de la realidad-, sorprendió a todos, empezando por la misma clase fotográfica. La sociedad quedó también perturbada pero, como correspondía a su ser histórico, de escasa memoria preventiva, el aviso fue sobreseído, con lo que su olvido fue casi instantáneo.

Empero, el arte (la conciencia histórica del hombre, su libertad conceptual primera), tierra fértil a toda semilla del asombro, no olvidó la lección, que venía a reforzar esa simbología de fin de mundo producida en las conciencias en el preciso instante de la presentación por Arago del hecho fotográfico, y sintetizada en la contundente sentencia delarochiana en la que se.venía a anunciar, con autoagresivo espíritu milenarista, que la pintura había muerto.

No se trataba de ningún exceso formal, sino de una firme y serena convicción: lo que había fallecido era la inercia servil, los pictoricismos de opereta, la servidumbre antiestética hacía el poder, el fatal costumbrismo académico.

Así que gobiernos, pueblos y naciones prosiguieron su cansino - a menudo, suicida - recorrido por la historia, pero la sociedad del arte estaba plenamente advertida, aunque casi habría que decir que se encontraba infectada por el fenómeno.

\section{ANTECEDENTES DE LA RUPTURA Y PROCLAMACIÓN DE LOS RESPETOS.}

En referencia a los anteriores conceptos sobre emancipación del artista y derrota de las viejas retóricas artísticas, Gombrich recoge, con toda agudeza y precisión, la esencia de esa inflexión rupturista y, a la vez regeneracionista, que trastocó el ordenancismo pusilánime de las artes 1. La fotografía había surgido como necesidad documentalista de una fase

1 «El desarrollo de la fotografía obligó a los artistas a ir más allá en sus experimentos y exploraciones. La pintura no necesitaba desempeñar una tarea que un ingenio mecánico podía 
cultural dominada prioritariamente por el eclecticismo y el pragmatismo el ideario luisfelipista-, en el que todo se aceptaba y todo se utilizaba siempre que ese hecho no conmoviese las estructuras del régimen o de la sociedad burguesa, un mismo denominador común de intereses solidarios de supervivencia. A toda costa se intentaba reforzar estéticamente las creencias (elitistas y colectivas) en pro de la mayestática utilidad del régimen. Y se accedía a ese propósito de salvaguardia por medio del uso y abuso de una simbología oficial apoyada en encuadres éticos falsos, en unos clichés duplicados -idea de engaño, de duplicidad-, repetidos hasta la saciedad y que el pueblo admitía como legítimos. Los directores del interés político y artístico - una misma moda, un mismo utilitarismo-, presentaban esas pérfidas acciones de repetición como sugestivas innovaciones.

Las artes servían fielmente al Estado - y al gusto social por la permanencia de las costumbres, cuya hipotética quiebra estimulaba el pánico colectivo, garante de las infamias institucionales-, actuando como potencias obedientes y exaltadoras de la mayor gloria dinástica y familiar. A la vez, esas artes esclavizadas servían como galeotes incansables que bogaban rítmicamente, mecánicamente también, a bordo de una entidad administrativa omnipotente, que nada veía y nada entendía. Ese barco engañosamente liberal atravesaba impávido los mares de las pasiones humanas y nacionales, mostrando airosa su arboladura conceptual, impulsada por vientos siempre conocidos en pos de rumbos siempre comprensibles, no distorsionantes, que relatasen a los creyentes sociales los diferentes fenómenos del amor, la libertad, la guerra o el poder. Se trataba de una filosofía del artificio que, sin embargo, lograba reunir innumerables adhesiones.

El silencio ético y la censura estética venían impuestas por siglos de autocomplacencia en la visión - por críticos y por autores del arte, unos y otros satisfechos de sus respectivos presentes morales- sobre la manifiesta perdurabilidad de los regímenes y academias, así como por la aparente superioridad moral de los directorios y personajes que tutelaban aquella pomposa marcha institucional por la senda de la historia. Era esa una didáctica neotrentina en la que la pusilanimidad imperaba como ley, y en la que el servilismo hacia los modelos admitidos se alzaba como norma inviolable.

realizar mejor y a menor coste». GOMBRICH, ERNST, H., Historia del Arte. Versión en español de Rafael Santos TorRoella sobre la edición en inglés de 1989. Alianza Editorial, Madrid, 1990, 547 páginas, vid. pág. 416 . 
En realidad, gobernantes y gobernados, artistas y mecenas, público y sistema, compartían un falso dominio del futuro, esto es, estaban asentados sobre el puro vacío. La sociedad y la política utilizaban el arte como un placebo, adormecedor eficaz de sus insomnios personales frente a sus duras conciencias, estimulador activo de sus estrechas confianzas y protector tolerante de amistades inmorales sin mesura.

Si la fotografía abandonaba su cometido originario de asistenta de las artes (la idea crítica de Baudelaire) y, aparte de recoger con precisión inimitable el detalle de la naturaleza o de las cosas -acción que ya de por sí limitaba drásticamente la utilidad convencionalista de las artes clásicas-, se introducía desvergonzadamente en el terreno de la imaginación sensible o de la escueta realidad, el desorden (en las instituciones, en las convicciones) estaba garantizado.

La primera reacción fue, sorprendentemente, una conjunción de caracteres y formalidades dispersas entre el provocador (la fotografía) y el provocado en premier lieu (la pintura); aunque el Salón de los Rechazados hubiese mostrado ya en 1863 a qué niveles llegaban los fervores revolucionarios en el ámbito de la pintura, angustias que primero fueron intensas dudas y después culminarian en abrumadoras contundencias operativas.

En los bajos del edificio neoclásico que sostenía el imponente estudio del fotógrafo parisino Nadar (Gaspard Félix Tournachon, 1820-1910), en el 35 del Boulevard des Capucins, tuvo lugar en abril de 1874 aquella célebre exposición en la que los proscritos del cenobio de las artes (Cézanne, Monet, Renoir, Morisot), representantes del arte irrisorio - por la displicencia descriptiva al respecto de parte del crítico Louis Leroy-, terminarían por triunfar, con total seriedad, sobre los infantilismos y ocurrencias amusantes al uso (fig. 3).

Fue aquella una brillante muestra de eclecticismo, tanto por los fugaces arrendatarios como por el sagaz arrendador. Pero fue también una hermosa disertación sobre las bondades de la solidaridad contributiva entre diferentes actuantes del arte, educados intuitivamente en los modales del respeto mutuo.

Audaces practicantes de una fenomenología del tiempo histórico, no les importaba (aunque no la despreciaban) la crítica social, que presentían duramente adversa. En consecuencia, se ofrecían al público, a sus pocos amigos y a sus inevitables enemigos, como ellos eran: sinceros, auténticos e ingenuos $y$, por tanto, honestos. Su desnudez material y formal hizo el efecto de una descarga a quemarropa sobre aquellos regimientos de las vanidades éticas del momento, entrenados diariamente en la matemática de servir disciplinariamente al versallismo triunfante, y que desfilaban en 
grandes bloques de rítmica soberbia ante una historia insobornable a la que nunca lograron engañar.

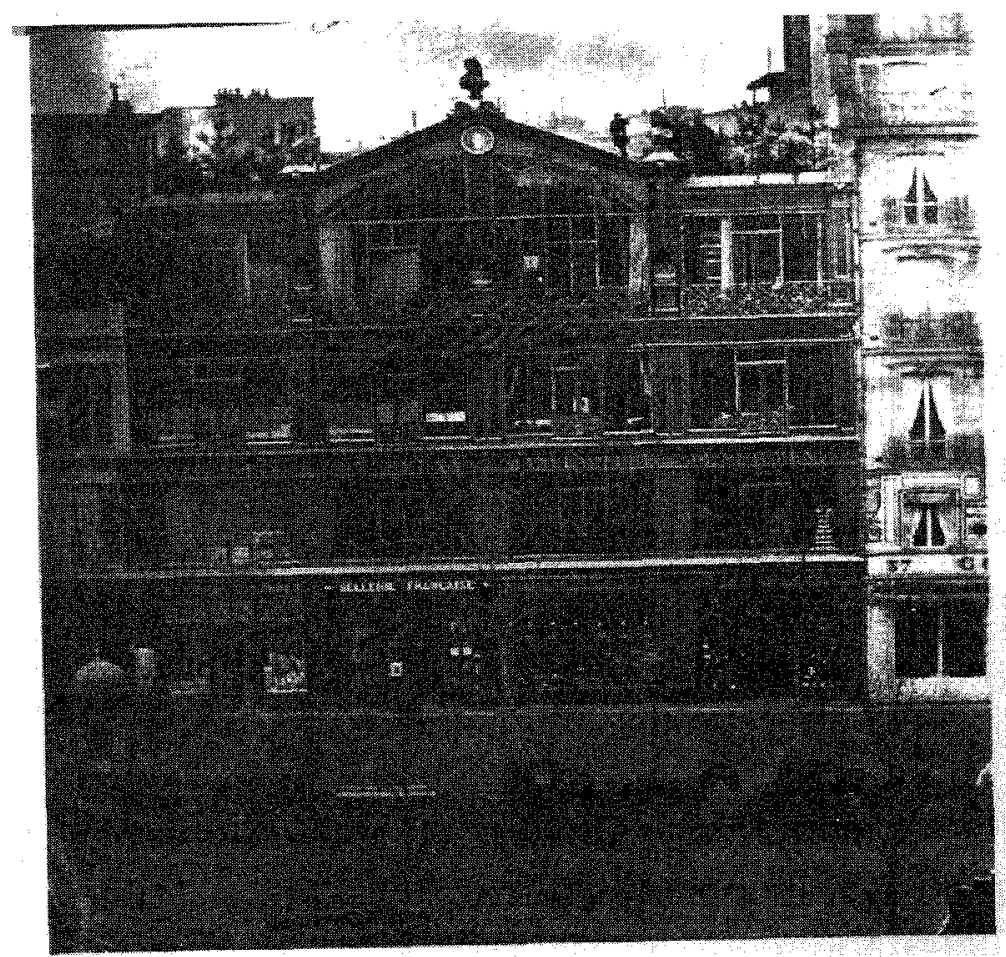

Fig. 3. Fachada del $n^{\circ} 35$ del Boulevard des Capucins, en París, estudio del fotógrafo Nadar. En los bajos de este edificio se celebró la famosa exposición de los Impresionistas. Autor anónimo, ca. 1880.

\section{LIBERTAD E IMAGINACIÓN EN EL ARTE. MITOS Y REALIDADES.}

Con su coraje sin límites, los impresionistas marcaron el camino regeneracionista a la pintura, mientras que a la misma fotografía la introducian en un reclinatorio conceptual y místico de connotaciones falsamente renacentistas. En efecto, al declinar el siglo, la fotografía, siempre fascinada por el aura senatorial de la pintura, trataría de parecerse obsesivamente a aquélla divinizada y poderosa matrona, autoimponiéndose ese vestuario nostálgico y soñador, de cuento encantado, que defenderían a muerte los pictorialistas como Gertrude Kasebier (1854-1934) o Alexander Keighley (1861-1947) (figs. 4 y 5). 


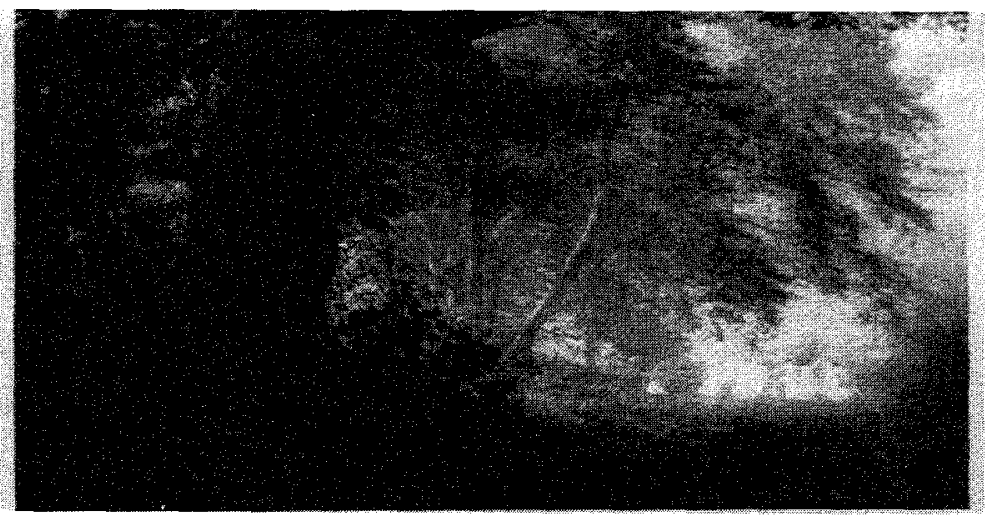

Fig. 4. Fantasy Original de AleXANDER KeIGHLEY. Proceso al carbón. Royarl Photography Society, Bath (Gran Bretaña).

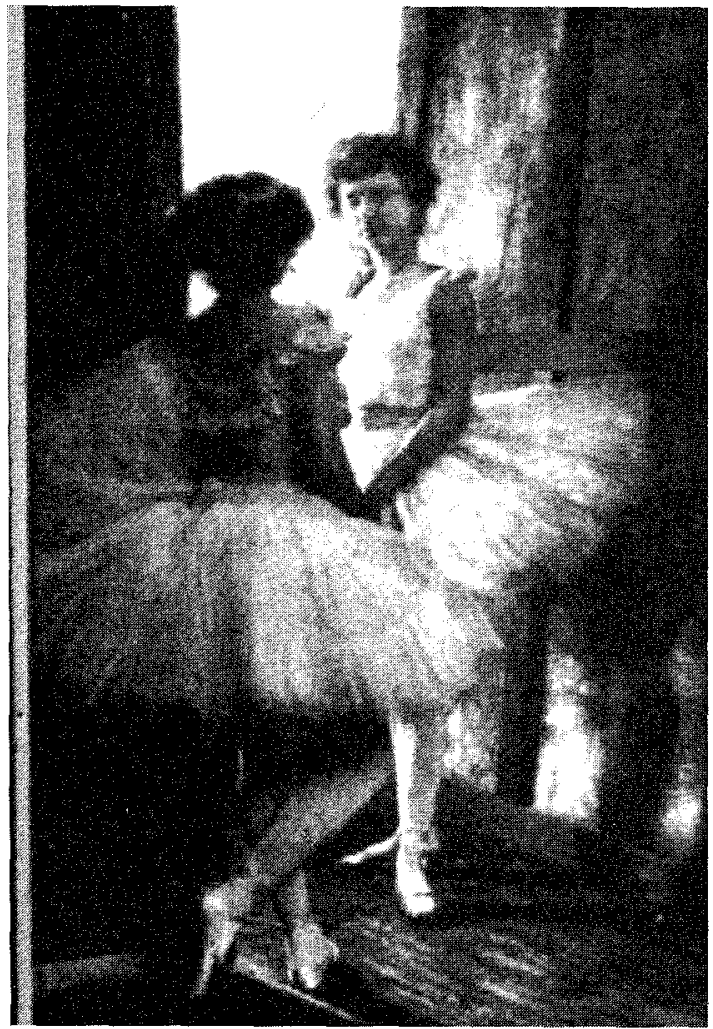

Fig. 5. Dans les coulisses (entre bastidores). Original de ROBERT DEMACHY. Goma bicromatada. The Metropolitan Museum of Art, New York. 
La pintura salía a trabajar al aire libre - los naturalistas-, y la fotografía pictorialista se encerraba en espacios conventuales, donde estudiaba trabajosamente sus barrocos complejos de absurda culpabilidad, de usurpadora obscena de la verdad artística. Para la mayoría de aquellos escuderos de la pintura no se trataba de sumisiones, ni tan siquiera de un simple acto de genuflexión ante la reina de las artes, se trataba de una supuesta fusión, una proclamación onírica de ambiciosa integración que resultó fallida.

Esta era la sana intención de un precursor como lo fue Peter Henry Emerson (1856-1936), primero fotógrafo pictorialista y más tarde famoso hereje del movimiento, al revolverse conceptualmente sobre si mismo y emprender la búsqueda de una realidad natural, sintetizada en su libro Naturalistic Photography for Students of the Art (1889) (fig. 6). Las críticas contra Emerson se amontonaron como piedras en una cantera, y aunque el desdichado profeta resistió cuanto pudo, una secuencia de debates con el pintor J. M. Whistler, le sumergieron en la duda, cayendo después en un fatalismo exaltado («la fotografía no es un arte puro»), romántico: su tétrico manifiesto The Death of Naturalistic Photography (1891), ribeteado con bordes negros. Emerson terminó negándose a sí mismo, practicante de un método que no le permitía independizarse de él - como si la pintura figurativa no se atuviera a una inflexibilidad modular-, y finalmente declaró, abrumado, que "la fotografía es un arte limitado»?

Tal actitud tenía su paradójica relevancia, porque en aquellos años las nuevas ópticas y las nuevas emulsiones fotográficas permitían la práctica de la instantánea, la vida en un momento. Esa interpretación sugestiva del movimiento oculto de los seres había sido ya investigada y probada audazmente por Eadweard Muybridge (1830-1904) en 1878 -las series del caballo Occident-, de la misma manera que Thomas Eakins (18441916) lograba encadenar en 1884-85, y a la milésima de segundo, el proceso mágico de un saltador de pértiga. A la par, la aparición de las denominadas cámaras de cajón, de las que la legendaria Kodak creada por George Eatsman fue la guía mundial a partir de 1888, confirió a lo familiar una inesperada importancia: la naturalidad cotidiana convertida en un suceso, la familia transformada en acontecimiento.

Fue entonces cuando los fotógrafos se sintieron ellos mismos amenazados por la tempestad de la vulgaridad gráfica, por la masividad de un

\footnotetext{
2 Newhall, Beaumont, Historia de la Fotografía. Desde sus orígenes hasta nuestros días. Versión en castellano de Homero Alsina Thevenet sobre la edición en inglés de 1982. Editorial Gustavo Gili, Barcelona, 1983, 349 páginas, vid. pág. 141-143.
} 


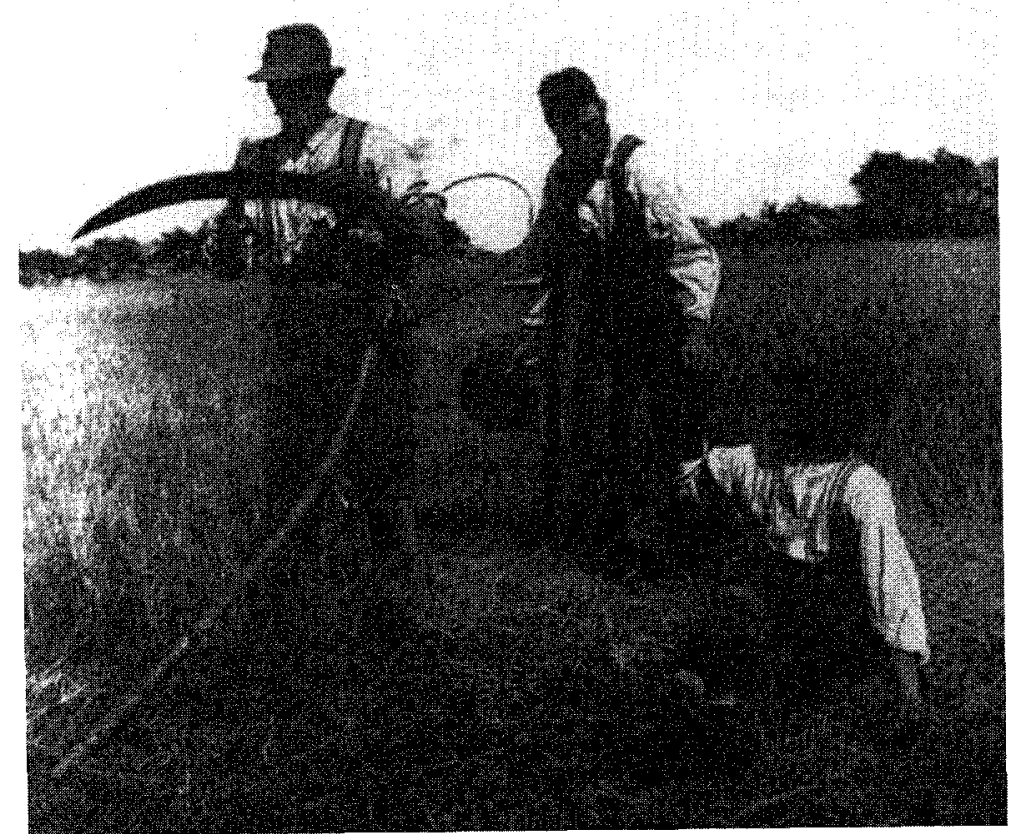

Fig. 6. In the Barley Harvest (En la Cosecha de Cebada). Original de PETER HENRY EMERSON. Fotograbado. Royal Photographic Society, Bath.

método puesto al alcance de cualquiera. El concepto de lo familiar, lo doméstico, tenía poco que ofrecer de ilusionante ante el carácter de lo quimérico, lo epopéyico, connatural al hombre fotográfico en sus orígenes.

El mito del creador de imágenes, supremo traductor de los sentimientos humanos, que laboraba enigmáticamente entre vapores de mercurio y emulsiones gelatinosas, gran hacedor del misterio de reproducir las emociones individuales y colectivas, genio que ensamblaba verosimilitud y eternidad, curiosidad social y trascendencia de clase, desaparecía definitivamente de la realidad. Por eso los pictorialistas se hicieron rápidamente fotógrafos pintores, y lo hicieron casi desesperadamente, como una reacción acantilada, apenas reflexiva ante el oleaje intimidante de las masas fotográficas. En el ámbito de la estética y sociología de lo militar, esas actitudes tuvieron devociones clamorosas, como lo certifican las series realizadas entre 1880 y 1895 , en las que la fascinación fotográfica hacia lo pictórico termina por hacerse suicidio mismo del hecho fotográfico. Pero 
ante el impresionismo, y después frente a la brillante imaginería de las vanguardias, los fotógrafos descubrieron, consternados, que habían dejado de ser dioses, tal y como les había ocurrido a los pintores en 1839.

Pintores y fotógrafos habían practicado el mutuo canibalismo plástico. Los primeros, habían trabajado en sus obras a partir de originales fotográficos, ya fuese a hurtadillas (Delacroix, Ingres, sobre todo) o a cara descubierta (Degas, Corot, Eliot, Rossetti, Wynfield), abastecidos de modelos (y de ideas) por los segundos, en tantos casos, íntimos amigos suyos: Cameron, Durieu, Dutilleux, Nadar ${ }^{3}$. De la misma forma, fotógrafos que se habían iniciado como pintores triunfaban en el nuevo género (Le Gray, Negre, Le Secq). Otros, beatos hasta lo indecible en el manierismo fotográfico, cometían doble perjurio: engañaban a la fotografía y lisiaban el fundamento pictoricista (Hill, Rejlander). Pese a estos abusos, y tanto social como políticamente, la preocupante fusión entre pintura y fotografía, símil de antirromanticismo práctico, vivía un auténtico essor en los años del tardorromanticismo esencial (1865-1885).

Lo más importante era la consolidación de un concepto de universalidad cognoscitiva del artista, que le llevaba a entender las artes no como un todo, sino como una suma, en la que los diferentes valores estaban claramente diferenciados, aunque su adición conducía a un dominio mayor del conocimiento.

Era el caso de genialidades interdisciplinarias como la de Etienne Carjat (1828-1906), quien, pese a utilizar su estudio fotográfico como un deuxiéme moyen -era pintor, caricaturista, editor y redactor en la revista Le Boulevard-, adquiriría con sus retratos una fama igual a la de Nadar y sus originales son hoy, para la crítica neutral, incluso superiores a los de su afamado rival de la época (fig. 7). Algo muy parecido sucedía con el escultor Adam Salomón (1811-1881), auténtico dictador estético de la sociedad parisina, que practicaba aquel arte complementario como un plaisir tédieux, y que solía citar a sus clientes con tres meses de antelación.

Pintura y fotografía convivían en una misma cabeza sacerdotal de la trascendentalidad del arte ${ }^{4}$. Desde esa bífida autoridad, uno tenía la fama y el poder, y el otro defendía la libertad y el derecho a ser diferente. Sin

\footnotetext{
3 STelzer, OTto, Arte y Fotografía. Contactos, influencias y efectos. Versión castellana de Michael Faber-Kaiser. Editorial Gustavo Gili, Barcelona, 1981, págs. 35-38.

4 Dice FREUND que "el pintor procuraba hacer de su pintura una descripción de la historia», mientras que "el fotógrafo crefa en la obligación de seguir al pintor por esa vfa». FREUND, GISĖLE, La fotografía como documento social. Versión castellana de Josep Elías sobre la edición en francés de 1974. Editorial Gustavo Gili, Barcelona, 1983, 207 páginas, vid. pág. 64.
} 


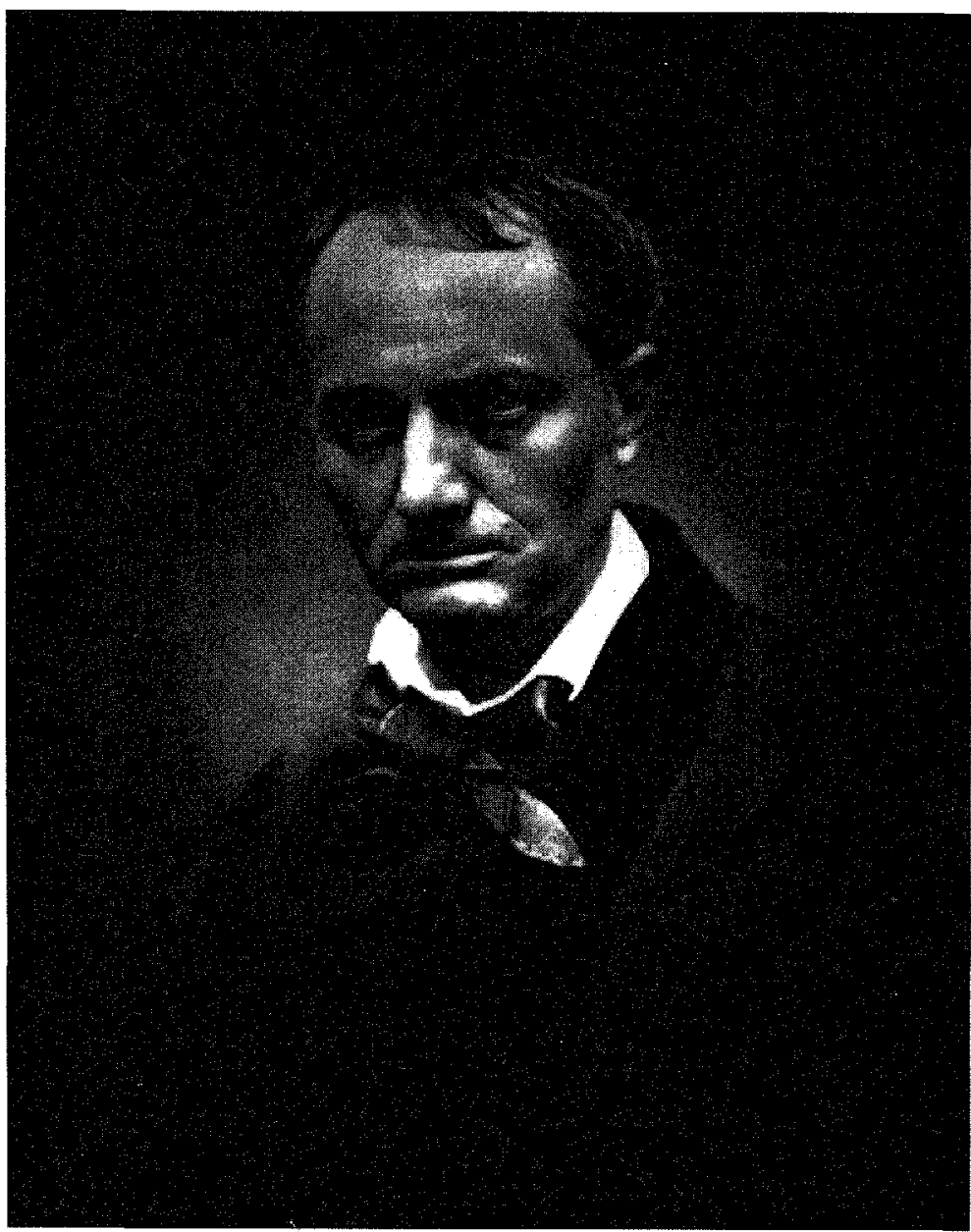

Fig. 7. Charles Baudelaire, Original de Etienne CARJAT perteneciente a su serie Galerie Contemporaine. Woodburytipo, 1878. International Museum of Photography, Rochester (EE.UU).

embargo, las dos posturas decían ser legitimas y verdaderas, aunque sus respectivas morales padeciesen fuertes escrúpulos de conciencia al respecto. En lo que concierne a sus respectivas andaduras socioestéticas, muy pronto esos caminos tomarían rumbos violentamente divergentes. De esa formidable bifurcación de energías se derivaría un sinnúmero de estímulos recíprocos, de intensas incentivaciones creadoras, para acceder a una posterior coincidencia en el objetivo final compartido: mantener la libertad del hombre, al menos en el arte. 
Aclara Sager que "cada tipo de realismo es distinto de la realidad" ${ }^{5}$. El acertijo tiene mucho que ver con la contemporaneidad de cada momento histórico. Esto nos lleva a estimar que cada época genera una poderosa inercia de procederes, de normas, reglamentación minuciosa que influye trágicamente sobre la infancia de las nuevas culturas, espacio frágil, delicado, en el que se desenvuelve la siguiente crisálida de la historia. Esas fuerzas exteriores a la realidad, por cuanto son de otro tiempo, inciden agresivamente en ese nido de las conciencias natales, al que someten a asfixiante sortilegio. La mayoría de las revoluciones políticas y artísticas han sido siempre consideradas prematuras por sus contemporáneos, adictos de la igualdad extrema entre permanencia y hechizo. Vencer a la realidad ha sido siempre el mal invencible para el hombre, imposibilitado de librarse de la brujería histórica de considerarse inmortal.

Esa energía, que es ya ahistórica (que no es lógica, incluso que no es legítima), guarda suficiente poder para alterar los subconscientes de sistemas, academias y nombres propios, que suelen sufrir hondas conmociones ante todo reformismo naciente. De la colisión entre realidad y fantasía, entre vanguardia y tradición, las fuerzas resultantes no suelen ser diáfanas, y de esta forma se obtienen melifluas y paralizantes combinaciones entre fantasía y tradición, o entre realidad y vanguardia. La primera convierte en una caricatura el derecho del pasado a ser asumido (respetado), y la segunda lleva a la revolución directamente a la burocracia (inmovilismo), al impedir el paso a toda imaginación.

El hecho fotográfico había sustraído a la pintura la transcripción de la realidad, y luego el utilitarismo de la fantasía, ya fuese monumental o doméstica. En su búsqueda diligente de una mayor facultad de rendimientos comunes para instituciones, gentes y cofradías de la ciencia o de los servicios, la fotografía se había transformado primero en un peligroso sustituto de la documentación minuciosa de cosas y personas, y finalmente en una suerte de apoderado notarial de la vida sensible. La pintura, un peu cinglée, vaciló fuertemente, oscilando entre la abulia alienante y la consternación pasional al dejar de ser la amada de la razón.

¿Cómo podría invertir la pintura esa posición incómoda, injusta y hasta peligrosa para el destino del arte? Desde luego no por la vía de un mayor detalle operativo en sus obras o por el método de reproducir exactamente las cosas y los seres. Para eso estaba ese despótico adversario, con sus

SAgeR, Peter: Nuevas formas de realismo. Versión española de Rosa Pilar Blanco Santos sobre la edición alemana. Alianza Editorial, Madrid, 1981, 264 páginas, vid. pág. 13. 
tecnicismos siempre mejorados, y su facilidad insultante para copiar al infinito modelos y situaciones. Los impresionistas habian abierto brecha: romper la monotonía, apartarse de lo dejà $v u$, reunir formas aparentemente contradictorias, mezclar colores antagónicos, era no una herejía, sino el restablecimiento de la religiosidad del pintor: la inventiva, el dinamismo, la iniciativa. En suma, salir del abismo, recuperar el puesto correspondiente en la historia. Gaugin, Munch, Seurat y Van Gogh habían señalado el camino. No estaban locos, la locura consistía precisamente en creer que la pintura podía sobrevivir sin sentir previamente, sin trasmitir ideas, sin presentar la emoción, sin ilusionarse ella misma de nuevo.

Había que salir del panteón de las pretéritas ilusiones. Y Gombrich es tajante al respecto: «En realidad, podíamos muy bien preguntarnos cómo es que el arte pudo adquirir la reputación de representar las emociones humanas" ${ }^{6}$.

\section{DIVISIONES Y MULTIPLICACIONES DEL SENTIR Y EL ENSEÑAR}

Como muy bien dice Jason, «el siglo xx empezó con cinco años de retraso" ${ }^{7}$, que son los que van desde 1901 a 1906, fechas en las que se suceden las exposiciones conmemorativas de los oscuros sacerdotes de la rebeldía (Cézanne, Gaugin, Van Gogh). Los jóvenes pintores, difíciles supervivientes de una belle époque que no perdonaba ni a los genios ni a los visionarios, quedaron literalmente dérangés ante la panorámica revolucionaria que, imprevistamente, resucitaba ante sus ojos. Ellos dudando entre convivir (renegar de los ideales) o morir (empeñarse en la defensa del ideal), y allí estaba la prueba del éxito histórico para los audaces: las obras heréticas recibian todas las alabanzas burguesas, las mejores calificaciones críticas, los más altos plácemes monetaristas. Les vieux monstres, tan vituperados, tan olvidados, tan inútiles, resultaba que eran la mejor inversión posible.

Uno de los primeros grandes absortos ante esta formidable exhumación de posibilidades fue Picasso. No tardaría mucho en reaccionar, por cuanto

\footnotetext{
6 Gombrich, ERNSt, H.: La imagen y el ojo. Nuevos estudios sobre la psicología de la representación pictórica. Versión española de Alfonso López Lago y Remigio Gómez Díaz sobre la edición en inglés de 1982. Alianza Editorial, Madrid, 1987, 302 páginas, vid. pág. 75.

JASON, H. W.: Historia general del arte. Versión español de Francisco Payarols. Primera edición en inglés de 1986. Alianza Editorial, Madrid, cuatro vols., tomo IV, El Mundo Moderno, págs. $981-1315$, vid. pág. 1.102 .
} 
su violentísima ofensiva antisistema - las señoritas de la calle de Aviñó, llegarian un año más tarde. Lo de menos eran los desnudos o el talante infame de vulgaridad (prostitución) subyacente en el cuadro, lo grave era que la visión fastidiosa de estos asuntos - siempre difíciles para la sociedad y el arte-era violada por un desgarro fulminante de volúmenes, proporciones y luces. El lienzo adquiría dimensiones de manifiesto, y esa proclama, dicha en un burdel con marco, convertía su contemplación en un atragantamiento convulso para sociedades y patricios.

Matisse, jefe de filas del fauvismo, aportó otra idea clave: la expresión. Y mientras el mundo se introducía en una inextricable contienda de fieras imperiales y nacionales en despedazamiento continuo, el arte rivalizaba en descuartizamientos, en resistencias dementes, en fastos centrípetos, en juveniles asaltos contra los padres dictatoriales del ser. Si hubo una guerra sin piedad e incruenta en el siglo $\mathrm{xx}$, guerra que no produjo ninguna ejecución excepto la de la inocencia, esa guerra fue la del arte consigo mismo y contra los vicios de la historia.

La paz llegó a los frentes de batalla, pero la pintura se mantenía en pie de guerra y ni pedía clemencia ni concedía cuartel: Braque, Delaunay, Duchamp, Gris, Kandinsky, Modigliani, Picasso siempre, Roualt, Stella, el grupo Die Brücke, convertirían el período de entreguerras en un conflicto inenarrable de formas, sentidos y provocaciones. Boccioni en la pintura y Archipenko y Etienne-Jules Marey en la escultura, con sus aplicaciones de la velocidad en los cuerpos, reforzaron este ideario aparentemente sin fundamentos, sin ley (fig. 8). Para muchos - entre ellos, bastantes fotógrafos, firmes defensores del clasicismo, como Antonio Cánovas del Castillo y Vallejo, Kaulak (1862-1933) - aquello era el caos, la muerte del arte. Es decir, la misma acusación angustiada que los pintores románticos difundieron ante las mareas daguerrotípicas. En este reordenamiento del mundo, la liturgia de los Manifiestos se hizo diaria: el de Marinetti en 1909 quedó en anécdota diletante -el futurismo era el presente-, mientras que el de Mondrian en 1917 se alzó como un verdadero canto a la dualidad del arte: exterioridad/interioridad, la duda hecha forma.

Ni qué decir tiene que la fotografía quedó anonadada. Por un lado perdía su referente, su grandiosa ejemplaridad tutora y, por el otro, quedaba relegada al papel de mero cronista de los sucesos, fuesen históricos o no. Habia perdido actualidad y singularidad, terribles conceptos que, en la constatación de sus pérdidas, y en el contexto de la competitividad tumultuosa de las vanguardias equivalían a la muerte moral.

El desencantamiento (la vuelta al realismo), vendría de la mano de autores intrépidos como Alfred Stieglitz (1864-1946), quien, en febrero de 


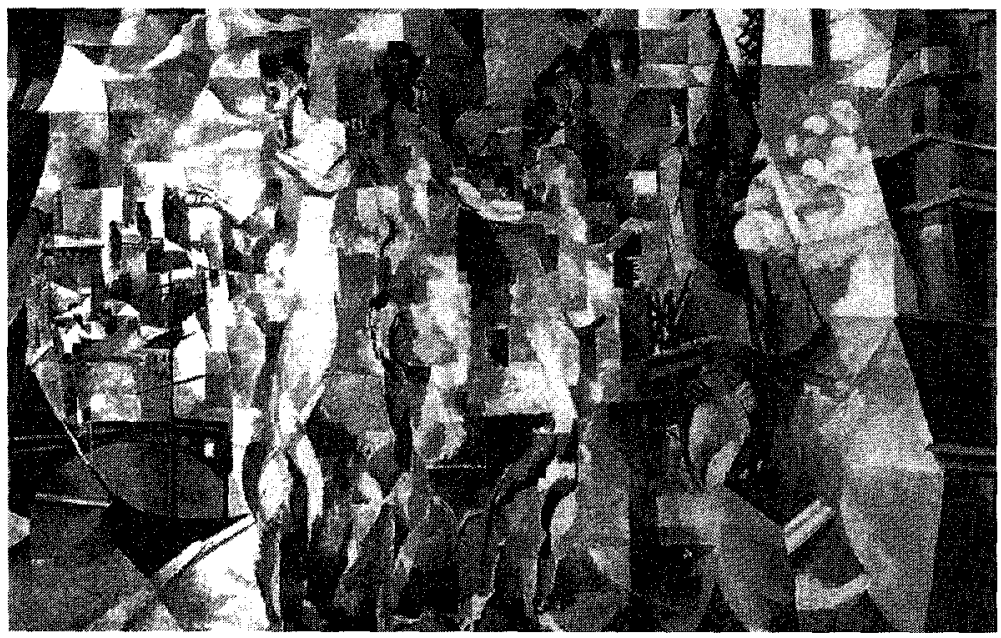

Fig. 8. La cité de Paris. Robert DeLAunAY, 1910-12. MNAM, París.

1902, formaría en Nueva York una sociedad para estimular el reconocimiento del ya viejo arte fotográfico, y a la que denominaría PhotoSecession, con evidentes similitudes formales con los movimientos de vanguárdia entonces triunfantes en Europa. Stieglitz era un pictorialista de renombre pero, sobre todo, un reformador impenitente de sí mismo. Testimonio de ello será, en 1907, su elocuente perspectiva de los dramas sociales: The Steerage, la visión abigarrada de un buque de emigrantes en el momento de su silente llegada al puerto neoyorkino (fig. 9).

La obra de Stieglitz, con parecernos hoy un clásico, en su momento era picassiana: cada figura es un drama, cada drama esconde un nombre, y la tragedia del conjunto, con ser anónima, es lúcidamente real y cognoscible. Multiplicaciones y subdivisiones para el conocer: la técnica del nuevo orden estético. El entrepuente stieglitziano antecede, moralmente, al Guernika: se trata de sendos bombardeos de la conciencia por la realidad sentida y la subjetividad vivida.

Recordaba Newhall que Stieglitz "quedó deleitado cuando a Pablo Picasso le gustó The Steerage" ${ }^{8}$. Los dos artistas renuncian, en el mismo año, a sus intimismos más recientes y queridos. Recordemos que el original de Stieglitz supone la ruptura con su pictorialismo más ortodoxo, de la

8 Newhall, B., op. cit, pág. 168. 


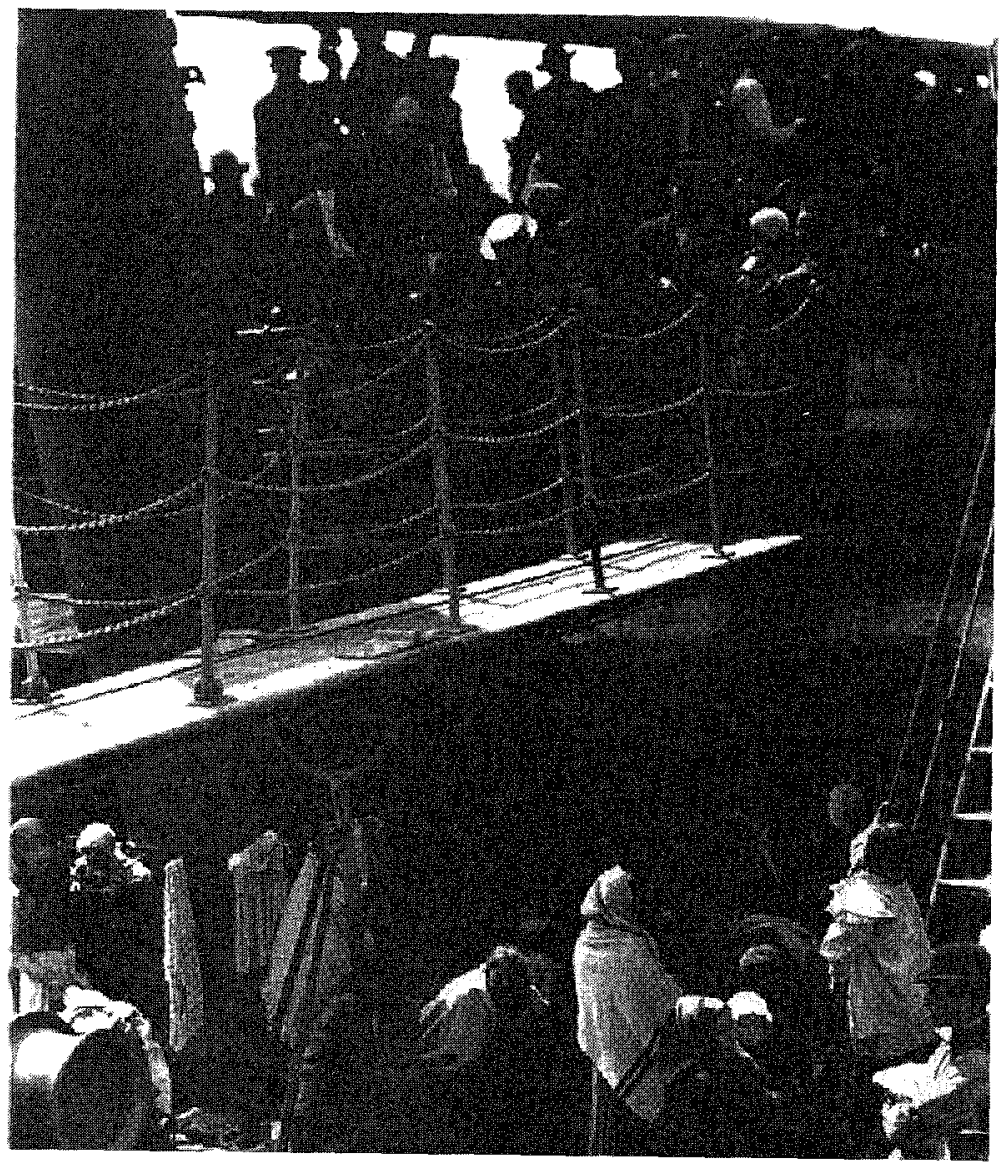

Fig. 9. The Steerage (EI Entrepuente). Original de Alfred STIEGLITZ. Fotograbado, 1907. The Museum of Modern Art, New York.

misma manera que el cubismo agresivo de Picasso liquida sin contemplaciones la fastuosidad pictórica de sus períodos azul y rosa.

Años después, Stieglitz, influido por el progresismo de Edward Steichen (1879-1973), establece en un local del 291 de la Quinta Avenida una sala de exposiciones de carácter múltiple. A partir de 1913, y hasta su rápido y oscuro final en 1921, la 291 fue el mayor faro del arte moderno, ámbito en el que confluían definiciones y voluntades con una fuerza fraterna sin igual. El espectáculo de la mítica 291 tenía mucho de visión alucinógena, una saturnal vertiginosa de emociones, contradicciones y verificaciones: las colisiones de Brancusi, los impactos cubistas de Picasso, o los vuelos 
litográficos de Rodin. Podría hablarse de un combate sin cuartel entre hombres (ideas) y bestias (costumbres). En ese festival de las sensibilidades quedó edificado, en aquella dulce época wilsoniana, un efímero recinto para espíritus puros, válido para reflexiones actuales: todavía hoy las artes viven en obsesivos compartimentos estancos, falsas seguridades corporativistas que facilitan la mudez abominable de la ética, el vértigo instigador de la autocomplacencia.

Todos, artes y autores, productores y consumidores, críticos y feriantes de la imagen, se observan sigilosamente entre sí mientras la nave de la realidad transporta a estas vitales circunstancias más allá de la razón práctica, aunque no fuera de la conciencia, donde deambulan, engreídas, opacas y mareadas, a través de la oceanidad tormentosa de una historia de las humildades perdidas que no cesa. 